\title{
Sero-Prevalence of Caprine Brucellosis in Babile Woreda, Eastern Hararghe, Ethiopia
}

\author{
Teferi Atlaw and Yeshibelay Girma* \\ Ministry of Agriculture and Livestock Resource, Addis Ababa, Ethiopia
}

Submission: February 14, 2019; Published: March 07, 2019

*Corresponding author: Yeshibelay Girma, Ministry of Agriculture and Livestock Resource, Addis Ababa, Ethiopia

\begin{abstract}
A cross-sectional study was conducted in six Peasant Association of Babile woreda. A sero-prevalence study of caprine brucellosis by using serological tests to determine the prevalence and the potential risk factors associated with brucellosis in the study area. Sera samples were collected from 384 unvaccinated and apparently healthy adult goats. The samples were examined serologically by Rose Bengal Plate Test (RBPT) for first screening test and Compliment fixation Test (CFT) for confirmations. All positive sera samples to RBPT were confirmed with CFT. Out of the total 384 samples were examined serologically $1.56 \%$ were reacted to be positive for RBPT screening tests and these positive samples continue to retest with CFT, it indicated as $0.78 \%$ prevalence of brucellosis from the examined samples. From the six-peasant association the highest sero-prevalence results recorded in CFT were Gemechu (1.75\%) followed by Bissedemo (1.37\%) and Shek Hussen (1.19\%). Caprine brucellosis sero-prevalence statistically not significantly difference $(P>0.05)$ on $\operatorname{sex}\left(\chi^{2}=0.274 ; P=0.600\right)$. The present study showed that caprine brucellosis is an endemic and widely distributed disease in goat, in the study area. In conclusion; In Ethiopia, domestic goats play an important role in the national economy. It has been estimated that there are approximately one hundred million domestic animals in Ethiopia, 23\% of which are goats upon this caprine brucellosis have a negative influence on both food security and important export commodity. Therefore: effective extension system and programs that could raise public health awareness on disease transmission to human and how to care and handle their animals. Control programs should be designed and implemented with the participation of all stakeholders (farmers, government, privet sectors and veterinarians). Further studies should be conducted on the high-risk groups and the associated risk factors of caprine brucellosis in different agro-ecology parts of the country.
\end{abstract}

Keywords: Babile woreda; Caprine Brucellosis; Sero prevalence; RBPT; CFT

\section{Introduction}

Ethiopia is an agriculturally based country and owns huge number of small animals which is estimated to be over 48.2 million head of sheep and goats. Majority of these animals are largely concentrated in pastoralists areas of the country [1]. The livestock subsector contributes some $45 \%$ of agricultural GDP, $15-18 \%$ of national GDP and 5-17\% total exports [2]. Sheep and goats are highly adaptable to broad range of environmental conditions. Moreover, low cost of production, requirement of little land and higher prolificacy made them attractive asset for development. Investment in sheep and goats avoid losses due to high inflation rates that are found in unstable economies of many developing countries like Ethiopia [1]. Goats are important in marginal agricultural land areas, especially in arid and semi-arid areas of Ethiopia [3]. This is primarily due to their better adaptation to harsh tropical environments and relative tolerance of feed scarcity in recurring droughts [4]. However, as in other tropical areas, productivity of goats in Ethiopia has been hindered by low reproductive performance of breeding flock [5]. The sufferance of animals with disease like brucellosis is one of the most recognized factors for low reproductive efficiency worldwide [6].

Brucellosis is a worldwide zoonotic infectious disease caused by gram-negative cocco-bacillary rod, bacteria from the genus brucella. Brucellosis, called undulant fever in man, remains an important disease that persists where the infection in animals has not been controlled where the transmission of the disease to humans is still common. Ruminants, swine and wild life contract for this zoonotic agent [7]. The goat was originally considered as the principal host of $B$. melitensis. Brucellosis, especially caused by Brucella melitensis, remains one of the most common diseases with major veterinary and public health significance worldwide with more than 500,000 human cases reported annually [8]. Brucellosis is an infectious bacterial disease caused by members of genus Brucella. It is a disease of worldwide importance and affects several animal species. Brucellosis in goats is primarily caused by brucella melitensis and sporadic infections due to brucella abortus and brucella suis have also been reported [9]. It is the disease of 
sexually matured animal with predilection for placentas, fetal fluids and testes of male animals [10].

The disease in naturally infected sheep and goats is characterized by abortion, stillbirth and birth of weak offspring in females and acute orchitis and epididymitis in males. Brucellosis is an important zoonosis causing chronic debilitating disease in man. Groups at higher risk for brucellosis are animal health workers, butchers, farmers and those who habitually consume raw milk and meet animals [11,12]. In Ethiopia, few studies have been published so far on small ruminant brucellosis [13]. Caprine brucellosis in sub-Saharan Africa is less commonly reported than brucellosis in cattle [14]. Similarly published information on goat brucellosis is scarce and is limited to few districts in Ethiopia [1517]. The lack of scientific information on the prevalence of this otherwise very important disease-causing public health hazard and heavy economic loss warranted the proposed study to contribute for future control measure in Ethiopia. Particularly, there is no published data on caprine brucellosis in the study area. On the other hand, there is high population of goat in the study area [1]. Therefore, the objectives of this study were to determine the sero-prevalence and assess possible risk factors of caprine brucellosis in the study area.

\section{Materials and Methods}

\section{Study Area}

The study was conducted in Babile woreda, eastern Hararghe Ethiopia. The area located $561 \mathrm{~km}$ away from the capital city (Addis Ababa) at 8³9'5999" N latitude and $42^{\circ} 24^{\prime} 5999^{\prime \prime}$ E longitude and the elevation is ranges from 1450- 1700 meters above sea level. The weather conditions characterized by semi-arid and arid climate with average annual temperature and the annual rain falls is ranged from 24 to $28{ }^{\circ} \mathrm{C}$ and 410 to $800 \mathrm{~mm}$ respectively. Agro pastoral and pastoral is the main occupation of the population of the area. According to Babile woreda agricultural office annual report [18] the livestock population estimated as 76,161 cattle, 11,470 sheep, 20,644 goats, 7,393 donkey, 15,430 camel and 21,114 poultry.

\section{Study Animals}

All the study Animals are indigenous Somali goat of both sexes in adult age and no history of vaccination against Brucellosis, kept under the extensive whereas, Goats which were diseased and who have had history of vaccination against brucellosis were excluded.

\section{Study Design}

A cross-sectional study was conducted by selecting animals randomly to determine the sero-prevalence of caprine brucellosis in the woreda and assess potential risk factors associated with sero-positivity.

\section{Sample size and sampling methodology}

The sample size was calculated by using the formula recommended by Thrusfield [19] for simple random sampling consider- ing 95\% confidence interval level and 5\% desired absolute precision. $50 \%$ expected prevalence was used as there was no previous study in the area.

$$
n=\frac{(1.96) \wedge 2 P \exp (1-p \exp )}{d \wedge 2}
$$

Where: $\mathrm{n}=$ required sample size; $\mathrm{P}_{\exp }=$ expected prevalence; $\mathrm{d}^{2}$ $=$ desired absolute precision of 95 confidence interval. The minimum sample size required as per the above formula is 384 . Simple random sampling technique was used to select peasant associations (PAs) and goats. Sera samples were collected from six selected PA (Sheik Hussein, Ellemo, Ifa, Bissedemo, Gemechu and Sheik Abdi) goats with no history of previous vaccination against brucellosis. Approximately $8 \mathrm{ml}$ of blood sample were collected from the jugular vein for serological examinations by using plain vacutainer tubes and needles. The sera were separated by centrifugation $\left(3,000 \mathrm{rpm}, 4^{\circ} \mathrm{C}\right.$ and $\left.10 \mathrm{~min}\right)$. Then sera removed from the clots by siphoning them into sterile cryovials. The sera were shipped with icebox to the Haramaya University Microbiology laboratory and stored at $-20^{\circ} \mathrm{C}$ until the screening test performed.

\section{Serological screening and Confirmation}

The test serum $(75-90 \mu \mathrm{l})$ was placed on a glass slide on to which Rose Bengal Plate Test antigen (RBPT) $(25-30 \mu \mathrm{l})$ was added. After mixing with a plastic applicator and shaking for 3-4min, the occurrence of agglutination was noted $[10,20,21]$. The agglutination test was repeated on those ambiguous results and positive sera were stored at $-20^{\circ} \mathrm{C}$ till further processed by complement fixation test (CFT). Sera with strong reaction at dilution of 1:5 with a strong reaction of approximately $100 \%$ fixation of the complement $(4+)$, more than $75 \%$ fixation of complement $(3+)$ at a dilution of $1: 5$ and at least $50 \%$ fixation of complement $(2+)$ at a dilution of $1: 10$ and 1:20 were classified as positive [10]. The test was done at the National Veterinary Institute (NVI) at Debre-Zeit, Ethiopia.

\section{Data storage and analysis}

The data collected from the field were recorded in the format developed for these purposes and later entered into Microsoft excel spreadsheet. Statistical analyses for categorical variables (sex and PA) were expressed in percentage. The prevalence is calculated by the proportions of the number of animals tested positive by the RBPT / CFT divided by the total number of animals tested. For all analysis p-value is less than 0.05 was taken as significant.

\section{Results}

The results of this sero-prevalence of caprine brucellosis in Babile woreda out of 384 serum sample tested by RBPT $1.56 \%$ (6/384) were found to be positive as shown Table 1 . RBPT positive $(n=6)$ sera retested with CFT only 3 sera were positive. The overall prevalence of Caprine brucellosis was $0.78 \%(3 / 384)$ in the six PA. There is no statistically significant different ( $p>0.05)$ were observed in the prevalence among the six PA as shown in Table 2 . The result also shown that there are no statistically sig- 
nificant differences in the sero-prevalence of caprine brucellosis in female and male goats were $0.85 \%$ and $0.00 \%$ respectively as shown in Table 3.

Table 1: Sero-prevalence of caprine brucellosis in the six PA with the RBPT.

\begin{tabular}{|c|c|c|c|}
\hline PA & $\begin{array}{c}\text { No. of serum } \\
\text { tested }\end{array}$ & Positive sera & Prevalence (\%) \\
\hline Sheik Hussein & 84 & 1 & 1.19 \\
\hline Ellemo & 63 & 2 & 3.17 \\
\hline Ifa & 23 & 1 & 4.35 \\
\hline Bissedemo & 74 & 1 & 1.37 \\
\hline Gemechu & 52 & 1 & 1.75 \\
\hline Sheik Abdi & 88 & - & 0.00 \\
\hline Total & 384 & 6 & 1.56 \\
\hline
\end{tabular}

$X^{2}=3.665$, the $P$-value $=0.599$, the result is not significant at $P<0.05$.

Table 2: Sero-prevalence of Caprine brucellosis in six PA with CFT.

\begin{tabular}{|c|c|c|c|}
\hline PA & $\begin{array}{c}\text { No. of serum } \\
\text { tested }\end{array}$ & Positive sera & Prevalence (\%) \\
\hline Sheik Hussein & 84 & 1 & 1.19 \\
\hline Ellemo & 63 & - & 0.00 \\
\hline Ifa & 23 & 1 & 0.00 \\
\hline Bissedemo & 74 & 1 & 1.37 \\
\hline Gemechu & 52 & 1 & 1.75 \\
\hline Sheik Abdi & 88 & - & 0.00 \\
\hline Total & 384 & 3 & 0.78 \\
\hline
\end{tabular}

$X^{2}=2.5427$, the $P$-value $=0.770$, the result is not significant at $P<0.05$.

Table 3: Sero-prevalence of Caprine Brucellosis in sex bases with both RBPT and CFT tests.

\begin{tabular}{|c|c|c|c|c|c|c|c|}
\hline Sex & $\begin{array}{l}\text { No. of } \\
\text { serum } \\
\text { tested }\end{array}$ & $\begin{array}{l}\text { RBPT } \\
\text { posi- } \\
\text { tive }\end{array}$ & $\begin{array}{l}\text { Prev- } \\
\text { alence } \\
(\%)\end{array}$ & & $\begin{array}{l}\text { CFT } \\
\text { posi- } \\
\text { tive }\end{array}$ & $\begin{array}{c}\text { Preva- } \\
\text { lence } \\
(\%)\end{array}$ & \\
\hline Male & 32 & 1 & 3.13 & $\begin{array}{c}\chi 2 \\
=0.554\end{array}$ & 0 & 0 & $\begin{array}{c}\chi^{2} \\
=0.274\end{array}$ \\
\hline $\begin{array}{l}\text { Fe- } \\
\text { male }\end{array}$ & 352 & 5 & 1.42 & $\begin{array}{c}P= \\
0.457\end{array}$ & 3 & 0.85 & $\begin{array}{c}P= \\
0.600\end{array}$ \\
\hline Total & 384 & 6 & 1.56 & & 3 & 0.78 & \\
\hline
\end{tabular}

$x^{2}=0.274$, the $P$-value $=0.600$, the result is not significant at $P<0.05$.

\section{Discussion}

In this cross-sectional study, attempt was made to have an insight on to the status of caprine brucellosis in the Eastern Hararghe, Babile woreda, six peasant associations. The overall sero-prevalence was found to be $1.56 \%$ and $0.78 \%$ in the RBPT and CFT tests respectively. The present finding is broadly comparable with $1.3 \%$ and $2.4 \%$ prevalence reported from Arsi and central highland of Ethiopia [22]; $1.3 \%$ from South-Omo [23]; $1.9 \%$ from Somali regional state [24]; $1.9 \%$ from southern and central Ethiopia [25]; 1.09\% from Yabello in sheep [26]; 1.56\% from Borena [27]; Ferede [28] who reported $0.87 \%$ prevalence in goats in and around Bahir-Dar; Bekele [29] reported prevalence rate of 1.9\% in goats in Jijiga area. However; the higher prevalence rates recorded compared to the present study by Verma \& Alemayehu \& Bertu [30,31], in India and Nigeria, respectively could be due to differences in agro-ecology and animal husbandry system. Other study reports shown higher prevalence in Somali by Bekele [29], with 3.2\%; in Afar region by Wesinew [32] with 4.8\% and Ashenafi [33], with $11.6 \%$ in the low lands of Ethiopia; El-Ansary [34], with $14.2 \%$ in sheep, $16.2 \%$ in goat in Sudan; PFE [35] with $14.2 \%$ in sheep in, $16.72 \%$ in goat in Pastoral area of Ethiopia and Benkirane [36] with $7.2 \%$ in sheep, $5.29 \%$ in goat in Morocco; Ashagre [16] with prevalence of $4.2 \%$ in goats reported in South Omo zone. This difference might be diagnostic assay, sampling technique, study area and sample size used. No statistically significant difference observed between males and females. However, in support of the present finding, Teshale, Ashenafi, Ashagrie; Bekele \& Abiot $[15,25,28,32,37]$ also reported the absence of statistically significant difference between the two sexes. This could be due to the small sample size of males. Males are also kept in the herd for shorter period which decrease their exposure to the disease.

\section{Conclusions and Recommendations}

The present study showed that caprine brucellosis is prevalent at a low rate among goat populations in Eastern Hararghe, Babile District. The sero-prevalence of caprine brucellosis was almost similarly distributed in the three peasant associations out of the six peasant associations. It could be concluded that the positive animal can be a potential risk factors to the free disease animals in the area, unless the management system is improved. Hence, we recommend that effective extension system and programs that could raise public health awareness on the disease transmissions to human and how to care and handle their animals. Control programs should be designed and implemented with the participation of all stakeholders (farmers, government, privet sectors and veterinarians). Further studies should be conducted on the highrisk groups and the associated risk factors of caprine brucellosis in different agro-ecology parts of the country.

\section{Acknowledgments}

First, we would like to sincerely thank Haramaya University, Faculty of Veterinary Medicine staff members for their unlimited supports and advices and our deepest gratitude goes to NVI (National Veterinary Institute) Debre Zeit for their laboratory facility providing and technical supports. Finally, we would like to thank all proponents to our works from beginning to end for their encouragement and faith to our successfulness.

\section{Conflicts of Interest}

We declare that there is no any conflict of interest.

\section{References}

1. Central Statistical Agency (CSA) (2012) Central Statistical Agency Agricultural sample survey, Volume II: Report on livestock and livestock characteristics, Addis Ababa, Ethiopia. 
2. IGADLPI (2010) Intergovernmental Authority on Development Livestock Policy Initiative Working Paper No. 2, Italy.

3. Aklilu Y and Catley A (2009) Livestock export from horn of Africa: an analysis of benefits by pastoralist wealth group and policy implication. Feinestin international center, Tufts University, USA.

4. Desta S and Coppock DL (2004) Pastoralism under pressure: tracking system change in southern Ethiopia. Journal of Human and Ecology, 32(4): 465-489.

5. Mekasha Y (2007) Reproductive traits in Ethiopia male goats with special reference to breed and nutrition. PhD thesis, Division of reproduction, department of clinical science, Faculty of veterinary medicine and animal science, Swedish university of agricultural science, Uppsala.

6. Ahmad M (2005) Seroepidemiology of caprine brucellosis in Jordan. Small Ruminant. Research, 58: 13-18.

7. FAO (2005) Capacity Building for surveillance and control of zoonotic diseases. FAO/WHO/OIE expert and technical consultation Rome, Italy, p. 14-16.

8. Seleem MN, Boyle SM, Sriranganathan N (2010) Brucellosis: a re-emerging zoonosis. Vet Microbiol 140: 392-398.

9. Verma DK (2013) Review Article: Brucellosis in animals and human beings with special reference to Indian sub-continent. Int J Int Sci Inn Tech Sec A 2(2): 43-56.

10. OIE (2008) Manuals of Diagnostic Tests and Vaccines for Terrestrial Animals. (mammals, birds and bees). ( $6^{\text {th }}$ edn), Office international des epizotics, Paris, pp. 974-982.

11. Radostits OM, Gay CC, Hinchcliff KW, Constable PD (2006) Veterinary Medicine: A textbook of the diseases of cattle, horses, sheep, pigs and goats. (10 ${ }^{\text {th }}$ edn), Elsevier Ltd. New York, USA, pp. 963-994.

12. Gupta VK, Verma DK, Rout PK, Singh SV, Vihan VS (2006) Polymerase chain reaction (PCR) for detection of Brucella melitensis in goat milk. Small Ruminant Research 65: 79-84.

13. Yohannes M, Degefu H, Tolosa T, Belihu K, Cutler R, et al. (2013) Brucellosis in Ethiopia. Afr J Microbiol Res 7(14): 1150-1157.

14. Mc Dermott JJ, Arimi SM (2002) Brucellosis in Sub-Saharan Africa: Epidemiology, control and impact. Veterinary Microbiology 90: 111-134.

15. Yibeltal M (2005) Sero-prevalence study of small ruminant brucellosis in selected sites of the Afar and Somali regions, Ethiopia. DVM thesis, Faculty of Veterinary Medicine, Addis Ababa University, Debre Zeit, Ethiopia.

16. Ashagrie T, Yosefe D, Tolosa T (2011) Brucellosis and associated risk factors in South Omo Zone, Southern Ethiopia Sero-prevalence of caprine. African Journal of Microbiology Research 5(13): 1682-1476.

17. Megersa B, Biffa D, Abunna F, Regassa A, God froid J, et al. (2011) Sero-prevalence of brucellosis and its contribution to abortion in cattle, camel, and goat kept under pastoral management in Borana, Ethiopia. Tropical Animal Health and Production 43: 651-656.

18. Babile Woreda data (2016) Agricultural office annual reports

19. Thrusfield M (2007) Sampling in Veterinary Epidemiology ( $3^{\text {rd }}$ edn), Blackwell Scientific Ltd, UK, pp. 214-256.

20. Ferreir A, Cardoso R, Dias I, Mariano I, Belo A, et al. (2003) Evaluation of a modified Rose Bengal and an indirect Enzyme-Linked Immunosorbent Assay for the diagnosis of B. melitensis infection in sheep. Veterinary Research 34: 297-305.

21. Garin-Bastuji B, Blasco J, Marin C, Albert D (2006) The diagnosis of brucellosis in sheep and goats, old and new tools AFSSA, France. Small
Ruminants Research 62: 63-70.

22. Tekelay B, Kassali 0 (1990) Brucellosis in sheep and goats in central Ethiopia. Bulletin of Animal Health and Production in Africa. 38: 23-35.

23. Mekuria M (2007) Sero-epidemiology of Brucellosis in small rumi-nants in Southern Ethiopia. MSC Thesis, Addis Ababa University, Faculty of Veterinary Medicine, Debrezeit, Ethiopia.

24. Mihretab B, Hassen M, Mulugeta T, Tolosa T (2011) Small ruminant brucellosis and community perception in Jijiga District, Somali Regional State, Eastern Ethiopia. Tropical Anima l Health and Production 43: 893-898.

25. Asmare K, Megersa B, Denbarga Y, Abebe G, Taye A, et al. (2013) A study on sero-prevalence of caprine brucellosis under three livestock production systems in southern and central Ethiopia. Trop Anim Health Prod 45: 555-560.

26. Teshale S, Muhie Y, Dagne A, Kidanemariam A (2006) Sero-prevalence of small ruminant brucellosis in selected districts of Afar and Somalia pastoral areas of Eastern Ethiopia and the impact of husbandry practice. Rev Med Vet 157(11): 557-563.

27. Megersa B, Biffa D, Abunna F, Regassa A, Godfroid H (2010) Seroprevalence of brucellosis and its contribution to abortion in cattle, Camel and Goat kept under pastoral management in Borana, Ethiopia. Trop Anim Health Prod 43: 651-656.

28. Ferede Y, Mengesha D, Mekonen G, melekot HM (2011) Study on the sero-prevalence of small ruminant brucellosis in and around Bahir Dar, North West Ethiopia. Ethiop Vet J 15: 35-44.

29. Bekele M, Mohammed H, Tefera M, Tolosa T (2011) Small ruminant brucellosis and Community Perception in Jijiga District, Somali Regional State and Eastern Ethiopia. J Trop Health Prod 43: 893-898.

30. Verma DK, Alemayehu A (2012) Sero-prevalence of Brucellosis in Goats and Sheep in Different Regions of India, using B. melitensis Soluble Antigen in Plate-ELISA. Research and Reviews: A J Biotechnol 2(2): 46-50.

31. Bertu WJ, Ajogi I, Bale JO, Kwaga JKP, Ocholi RA (2010) Sero-epidemiology of brucellosis in small ruminants in Plateau State, Nigeria. Afr J Microbiol Res 4(19): 1935-1938.

32. Wesinew A, Moti Y, Hailu D, Tadele T (2013) Control and prevalence of brucellosis in small ruminants: time for action. J Vet Res 170: 97-98.

33. Ashenafi F, Teshale S, Ejeta G, Fikru R, Laikemariam Y (2007) Distribution of brucellosis among small ruminants in the pastural region of Afar, Eastern Ethiopia. Faculty of Veterinary Medicine, Addis Ababa University, Debre Zeit, Ethiopia and National Animal Health Research Center, Sebeta, Ethiopia. Rev sci Technol 26(3): 731-739.

34. El-Ansary EH, Mohammed BA, Hamad AR, Karon AG (2001) Brucellosis among animals and human contacts in Eastern Sudan. Saud Med J 22(7): 577-579.

35. PFE (Pastoralist Forum Ethiopia) (2004) Background to the Ethiopian livestock industry. In Pro. $3^{\text {rd }}$ National Conference on Pastoral Development in Ethiopia: Pastoralism and sustainable pastoral development, 23-24 december Addis Ababa, Ethiopia, p. 78-79.

36. Benkirane A (2006) Ovine and caprine Brucellosis. World distribution and control/ eradication strategies in west. Department MIMC, IAV Hassan II, BP 6202, Rabat-Institute, Rabat, Morocco.

37. Abiot D, Tesfaye S, Getachew T (2015) Sero-prevalence and risk factors of small ruminant brucellosis in selected districts of Arsi and East Shoa zones, Oromia region, Ethiopia. African Journal of Microbiology Research 9(19): 1338-1344. 
- Quality Editorial service

- Swift Peer Review

- Reprints availability

- E-prints Service

- Manuscript Podcast for convenient understanding

- Global attainment for your research

- Manuscript accessibility in different formats ( Pdf, E-pub, Full Text, Audio)

- Unceasing customer service

Track the below URL for one-step submission https://juniperpublishers.com/online-submission.php 